\title{
PROPAGASI VEGETATIF RUMPUT LAUT Gracilaria sp. MELALUI KULTUR JARINGAN
}

\author{
Sri Redjeki Hesti Mulyaningrum*), Rohama Daud*), dan Badraeni**) \\ *) Balai Penelitian dan Pengembangan Budidaya Air Payau \\ Jl. Makmur Dg. Sitakka No. 129, Maros 90512, Sulawesi Selatan \\ E-mail: titut_suryanto@yahoo.com \\ **) Fakultas Perikanan dan IImu Kelautan Universitas Hasanuddin \\ Jl. Perintis Kemerdekaan Km.10, Makassar, Sulawesi Selatan 90245
}

(Naskah diterima: 19 Mei 2014; Disetujui publikasi: 10 Juli 2014)

\begin{abstract}
ABSTRAK
Kultur jaringan merupakan salah satu metode untuk menghasilkan bibit rumput laut secara kontinu. Penelitian ini bertujuan untuk mengevaluasi pertumbuhan dan perkembangan bibit rumput laut Gracilaria sp. pada setiap tahapan proses propagasi vegetatif melalui kultur jaringan. Propagasi di laboratorium dilakukan selama 60 hari menggunakan kontainer kaca berkapasitas 2 L dengan kepadatan eksplan 1.000; 1.500; dan 2.000 eksplan/kontainer, selanjutnya dilakukan aklimatisasi eksplan di tambak menggunakan hapa berukuran $50 \mathrm{~cm} \times 50 \mathrm{~cm} \times 50 \mathrm{~cm}$ selama 60 hari dengan kepadatan eksplan 10, 20 dan $30 \mathrm{~g} / \mathrm{hapa}$. Propagasi di tambak dilakukan selama lima bulan dengan metode long line dan setiap 30 hari dilakukan perbanyakan bibit dan pengamatan terhadap pertumbuhan. Desain penelitian adalah rancangan acak lengkap dengan tiga ulangan untuk masing-masing perlakuan. Parameter yang diamati adalah sintasan eksplan di laboratorium, pertumbuhan, dan perkembangan bibit. Hasil yang diperoleh pada kultur di laboratorium yaitu sintasan tertinggi $(45,38 \%)$ diperoleh pada kepadatan 1.500 eksplan/kontainer, pada aklimatisasi di tambak kepadatan eksplan hingga $30 \mathrm{~g}$ tidak memberikan pengaruh yang nyata terhadap laju pertumbuhan harian bibit $(P>0,05)$; bobot mutlak tertinggi diperoleh pada perlakuan $30 \mathrm{~g} / \mathrm{hapa}$. Laju pertumbuhan bibit rumput laut hasil kultur jaringan pada propagasi di tambak berada pada kisaran $2,33 \%-4,31 \%$.
\end{abstract}

KATA KUNCl: propagasi, vegetatif, Gracilaria sp., kultur jaringan

ABSTRACT: Vegetative propagation of seaweed Gracilaria sp. by tissue culture. By: Sri Redjeki Hesti Mulyaningrum, Rohama Daud, and Badraeni

Tissue culture is a method to produce seaweed seed continuously. This study aimed to evaluate the growth and development of Gracilaria sp. seed at each stage of vegetative propagation through tissue culture. Laboratory propagation was done for 60 days using 2 L glass container with explants density of 1,000; 1,500; and 2,000 explants/container. Further, pond acclimation was done for 60 days using $50 \mathrm{~cm} x$ $50 \mathrm{~cm} \times 50 \mathrm{~cm}$ hapa with explants density of 10,20, and $30 \mathrm{~g} /$ hapa. Propagation in ponds was done for five months with a long line method, and seed multiplication and growth monitoring was performed every 30 days. The study was a completely randomized design with three replicates for each treatment. Observed parameters were explants survival rate in laboratory, the growth and development of seed. The results in the laboratory culture showed that, optimum survival rate was $45.38 \%$ on explants density of 1,500 explants/container. In pond acclimation, densities 
differences up to 30 grams have not significantly different on daily growth rate $(P>0.05)$, the best absolute weight was in $30 \mathrm{~g} /$ hapa treatment. The daily growth rate of seaweed seed in pond propagation were $2.33 \%-4.31 \%$.

\section{KEYWORDS: propagation, vegetative, Gracilaria sp., tissue culture}

\section{PENDAHULUAN}

Volume produksi rumput laut dunia terus meningkat dari 3,8 juta ton pada tahun 1990 menjadi 19 juta ton pada tahun 2010 , Indonesia sejak tahun 1985 telah menjadi salah satu negara sumber rumput laut tropis terbesar kedua setelah Cina. Salah satu spesies yang mengalami peningkatan produksi dari tahun 1990 hingga 2010 adalah Gracilaria sp. (FAO, 2012). Gracilaria sp. merupakan bahan baku agar yang utama, sekitar $80 \%$ total produksi agar di dunia bersumber dari Gracilaria sp. dan 20\% bersumber dari Gelidium sp. Permintaan pasar dunia terhadap rumput laut Gracilaria sp. terus meningkat, hal ini terlihat dari peningkatan total produksi agar di Eropa, Afrika, Amerika, dan Asia Pasifik yang mengalami peningkatan sebesar 2,8\% setiap tahun pada dekade 1999-2009 (Bixler \& Porse, 2011).

Gracilaria sp. merupakan jenis rumput laut yang banyak dibudidayakan di tambak dan budidayanya telah berhasil dilakukan di Chili dan Indonesia. Salah satu permasalahan yang sering dihadapi pada budidaya rumput laut adalah ketersediaan bibit yang kontinu untuk mendukung kegiatan budidaya. Perkembangan penelitian tentang alga akhir-akhir ini difokuskan pada penelitian bioteknologi, aplikasi budidaya mikro dan makro alga serta pengembangan produk alga (Tseng, 2004). Kultur jaringan merupakan salah satu upaya untuk menyediakan bibit rumput laut secara kontinu. Dengan kultur jaringan memungkinkan untuk produksi bibit dalam jumlah yang banyak dengan waktu yang relatif singkat (Yokoya \& Valentin, 2011). Lebih lanjut dijelaskan oleh Cecere et al. (2011) produksi propagul multiseluler memiliki kontribusi pada peningkatkan kapasitas spesies untuk meningkatkan populasi, ketersediaan plasma nutfah pada kondisi perubahan lingkungan yang tidak dapat diprediksi, dan untuk mendapatkan habitat baru.

Metode vegetatif seperti fragmentasi langsung dan pemotongan talus merupakan metode yang sering digunakan pada perbanyakan makro alga pada skala budidaya dan laboratorium (Simpson et al., 1979; Skurzynski \& Bocia, 2011 ; Yokoya et al., 2003). Metode tersebut juga digunakan pada penelitian ini, di mana propagasi bibit dilakukan secara in vitro di laboratorium kemudian dilanjutkan dengan aklimatisasi dan propagasi di tambak. Aklimatisasi dilakukan agar bibit rumput laut yang dihasilkan secara in vitro dapat beradaptasi dengan lingkungan budidaya, sedangkan propagasi di tambak dilakukan untuk memproduksi bibit rumput laut hasil kultur jaringan secara massal dan dapat dimanfaatkan dalam kegiatan budidaya. Penelitian mengenai kultur jaringan telah dilakukan sebelumnya di BPPBAP Maros, namun evaluasi secara menyeluruh mengenai pertumbuhan dan perkembangan eksplan dari kultur in vitro hingga propagasi di tambak belum banyak dilakukan.

Penelitian ini bertujuan untuk mengevaluasi pertumbuhan dan perkembangan bibit rumput laut Gracilaria sp. pada setiap tahapan proses propagasi vegetatif melalui kultur jaringan.

\section{BAHAN DAN METODE}

\section{Propagasi di Laboratorium}

Propagasi di laboratorium dilakukan melalui kultur jaringan di Balai Penelitian dan Pengembangan Budidaya Air Payau (BPPBAP), Maros. Bibit rumput laut diperoleh dari hasil seleksi varietas terbaik (Pong_Masak et al., 2011 ). Bibit dibawa ke laboratorium menggunakan kontainer dan ditutup dengan kain basah, kemudian dipilih talus yang sehat, bersih, dan bebas epifit. Talus kemudian dipotong-potong sepanjang $1 \mathrm{~cm}$ dan dicuci menggunakan air laut steril. Eksplan yang terpilih kemudian disterilisasi dengan metode sterilisasi permukaan (Polne-Fuller \& Gibor, 1984; Huang \& Fujita, 1997). Eksplan dicuci dengan detergen cair $0,5 \%$ dalam air laut steril selama sepuluh menit, selanjutnya disterilkan dengan betadin $2 \%(\mathrm{w} / \mathrm{v})$ dalam air laut steril untuk menghilangkan mikroba. Kultur dilakukan dalam kontainer kaca berkapasitas 2 L menggunakan media PES 1/20 (Provasoli, 
1968). Perlakuan kepadatan yang diujikan adalah: (A) 1.000 eksplan/kontainer; (B) 1.500 eksplan/kontainer; dan (C) 2.000 eksplan/ kontainer, dengan tiga ulangan untuk masingmasing perlakuan. Jumlah total eksplan pada akhir kultur dihitung untuk menentukan persentase sintasan.

Kultur di laboratorium dilakukan selama 60 hari, kemudian dilanjutkan dengan aklimatisasi di tambak. Analisis data dilakukan dengan analisis ragam ANOVA pada taraf kepercayaan 95\% dan uji lanjut LSD.

\section{Aklimatisasi di Tambak}

Aklimatisasi dilaksanakan di tambak percobaan Desa Taipa Kabupaten Takalar. Bibit rumput laut Gracilaria sp. hasil kultur jaringan dipelihara dalam hapa hijau berukuran $50 \mathrm{~cm}$ $\times 50 \mathrm{~cm} \times 50 \mathrm{~cm}$ dengan perlakuan kepadatan yakni: $A=10 \mathrm{~g} /$ hapa; $B=20 \mathrm{~g} /$ hapa dan $\mathrm{C}=30 \mathrm{~g} /$ hapa. Hapa diikat pada pancang bambu dengan ketinggian $15 \mathrm{~cm}$ di atas dasar tambak (Gambar 1). Desain penelitian adalah rancangan acak lengkap dengan tiga ulangan untuk masing-masing perlakuan. Pemeliharaan eksplan dilaksanakan selama 60 hari dan setiap 15 hari dilakukan penggantian hapa, pengukuran bobot, dan panjang bibit. Pengamatan perkembangan bibit dilakukan setiap minggu dengan mengambil gambar bibit rumput laut Gracilaria sp. menggunakan kamera.

Laju pertumbuhan bobot harian dihitung menggunakan rumus Dawes et al. (1993) berikut:

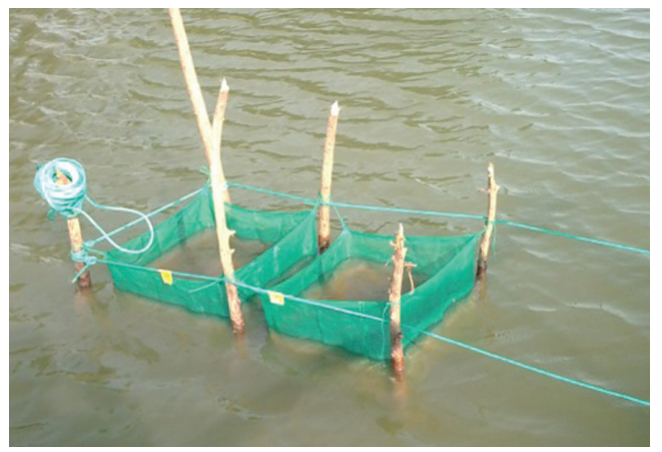

Gambar 1. Hapa untuk penebaran bibit rumput laut Gracilaria sp. hasil kultur jaringan

Figure 1. Net cage for seedling of seaweed Gracilaria sp. derived from tissue cultur
LPH bobot $(\% /$ hari $)=\frac{\ln W t / \text { Wo }}{t} \times 100 \%$

di mana:

$\mathrm{Wt}=$ Bobot bibit $(\mathrm{g})$ pada $\mathrm{t}$ hari

Wo $=$ Bobot awal bibit $(\mathrm{g})$

$\mathrm{t}=$ Masa pemeliharaan (hari)

Panjang eksplan diukur dari pangkal hingga ujung tunas dan laju pertumbuhan panjang harian dihitung menggunakan rumus berikut:

$$
\text { LPH panjang }(\% / \text { hari })=\frac{\ln \mathrm{Lt} / \text { Lo }}{\mathrm{t}} \times 100 \%
$$

di mana:

$$
\begin{aligned}
& \mathrm{Lt}=\text { Panjang bibit }(\mathrm{g}) \text { pada } \mathrm{t} \text { hari } \\
& \mathrm{Lo}=\text { Panjang awal bibit }(\mathrm{g}) \\
& \mathrm{t}=\text { Masa pemeliharaan (hari) }
\end{aligned}
$$

Data yang diperoleh dianalisis ragam (ANOVA, $p=0,05$ ), sedangkan data perkembangan bibit disajikan secara deskriptif.

\section{Propagasi di Tambak}

Propagasi di tambak dilakukan untuk memproduksi bibit rumput laut Gracilaria sp. hasil kultur jaringan secara massal. Perbanyakan dilakukan selama lima bulan yakni pada bulan Juni-Oktober 2013, sampai diperoleh bibit rumput laut hasil kultur jaringan yang siap digunakan dalam kegiatan budidaya. Perbanyakan dilakukan setiap 30 hari dengan metode long line dan dilakukan monitoring terhadap pertumbuhan dan kualitas air. Pertumbuhan diukur dengan menimbang rumput laut pada setiap bentangan dan laju pertumbuhan harian dihitung menggunakan rumus Dawes et al. (1993).

\section{HASIL DAN BAHASAN}

\section{Propagasi di Laboratorium}

Propagasi di laboratorium dilakukan selama delapan minggu dengan sintasan eksplan pada kisaran $28,07 \%-45,38 \%$. Sintasan tertinggi $(45,38 \%)$ diperoleh pada kepadatan 1.500 eksplan/kontainer dan sintasan terendah $(28,07 \%)$ diperoleh pada kepadatan 1.000 eksplan/kontainer (Gambar 2).

Kepadatan yang berbeda memberikan pengaruh yang nyata terhadap sintasan eksplan $(P<0,05)$. Uji lanjut LSD juga memperlihatkan perbedaan yang nyata antar perlakuan $(P<$ $0,05)$. Sintasan mulai mengalami penurunan 


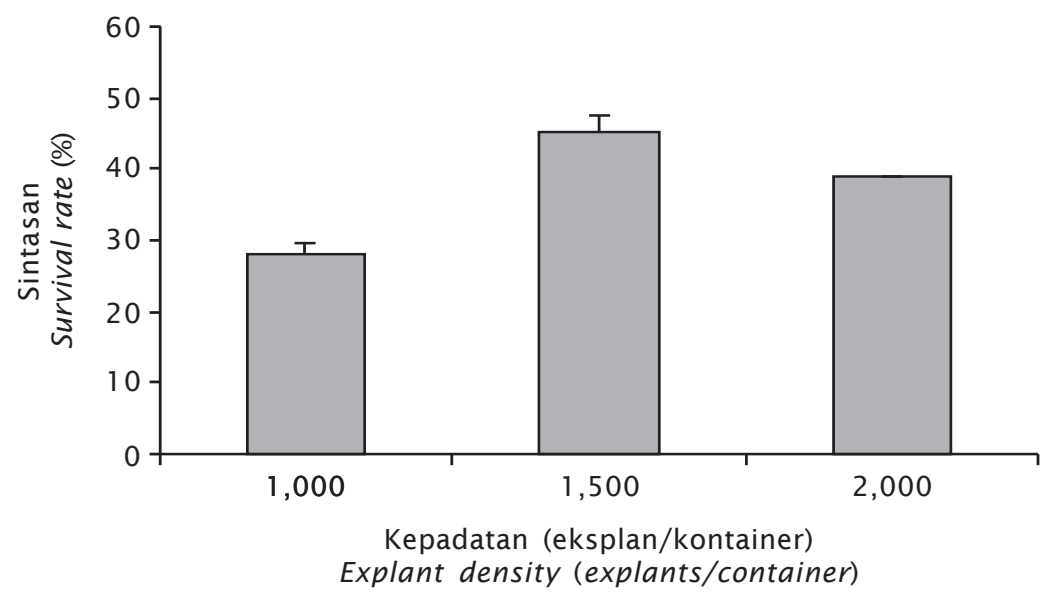

Gambar2. Sintasan eksplan pada kepadatan yang berbeda pada akhir penelitian di laboratorium

Figure 2. Survival rate in different explants density at the end of laboratory experiment

pada minggu pertama kultur (Gambar 3). Hal ini dikarenakan pada awal kultur, eksplan baru beradaptasi dengan lingkungan kultur. Menurut Yong et al. (2014), kepadatan memiliki hubungan yang negatif terhadap sintasan, namun pada penelitian ini kepadatan 1.500 eksplan/kontainer memiliki sintasan yang lebih tinggi dibandingkan dengan kepadatan 1.000 eksplan/kontainer, hal ini diduga karena faktor inhibisi media, di mana unsur utama pada media PES adalah mikro nutrien yang dalam jumlah berlebih bersifat racun. Pada kepadatan 1.000 eksplan/kontainer peman- faatan mikro nutrien oleh eksplan terlalu tinggi sehingga mengakibatkan kematian yang tinggi, hal ini sesuai dengan pendapat George \& Sherrington (1984) bahwa volume media kultur memiliki interaksi dengan kepadatan dalam memengaruhi pertumbuhan dan perkembangan eksplan, lebih lanjut dijelaskan bahwa interaksi tersebut berhubungan dengan faktor inhibitor pada media. Faktor yang memengaruhi sintasan eksplan pada kultur di laboratorium adalah proses kultur, di mana kondisi kultur dengan pencahayaan dan pengadukan media secara kontinu, serta peng-

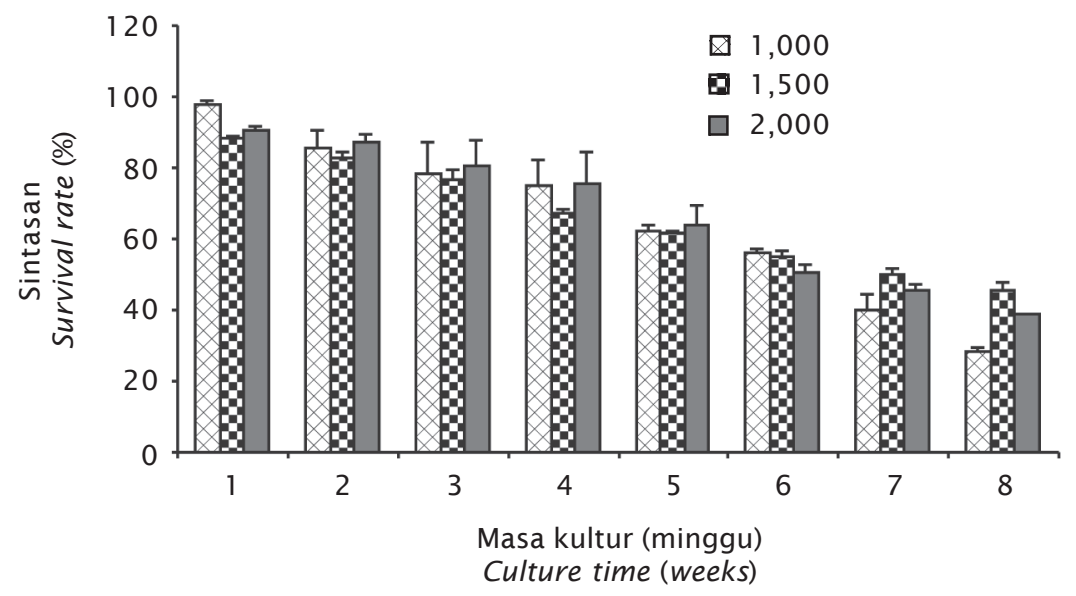

Gambar 3. Sintasan eksplan selama propagasi di laboratorium

Figure 3. Survival rate of explant during laboratory propagation 
gantian media dan pemindahan eksplan secara periodik dapat mengakibatkan kematian eksplan (Huang et al., 1998). Meskipun penggantian media secara periodik dapat mengakibatkan kematian eksplan, namun hal ini perlu dilakukan untuk memperbaharui komposisi nutrien karena selama proses kultur di laboratorium terjadi penurunan komposisi nutrien pada media.

Setelah delapan minggu masa kultur tunas mulai terbentuk pada bagian sayatan eksplan (Gambar 4), secara umum tidak terdapat perbedaan pada panjang dan jumlah tunas pada setiap perlakuan. Proses pemotongan eksplan menyebabkan pori-pori talus terbuka dan memudahkan proses penyerapan nutrien yang terdapat pada media kultur dan memacu pertumbuhan tunas. Kondisi kultur yang meliputi suhu, radiasi cahaya, dan salinitas juga memberikan efek stimulasi terhadap pertumbuhan rumput laut (Yokoya et al., 1999; Luhan \& Sollesta, 2010), pada penelitian ini suhu, pencahayaan, dan salinitas dirancang secara homogen di laboratorium.

Pertumbuhan tunas yang terjadi pada bagian sayatan eksplan merupakan efek dari penyembuhan luka yang bertepatan dengan perubahan habitat dan kompetensi eksplan untuk beregenerasi. Struktur vegetatif Gracilariaceae terdiri atas dua bagian, yakni: korteks dan medular. Korteks terdiri atas selsel yang berisi sitoplasma dan terhubung dengan sel-sel induk dengan koneksi primer. Medular tersusun atas sel-sel isodiametrik, sel tersebut memiliki vakuola dan beberapa koneksi sekunder dan koneksi primer. Pada proses kultur jaringan, dilakukan pemotongan ta- lus rumput laut Gracilaria sp. sehingga bagian terluar sel terluka dan kehilangan sitoplasma sehingga hanya tersisa dinding sel, namun pada bagian dalam sel tetap utuh. Kemudian terjadi proses sitokinesis di dalam sel korteks dan bagian terluar medular sehingga sel-sel baru terbentuk sepanjang permukaan yang disayat, selanjutnya dinding sel dari sel-sel baru secara bertahap akan menebal. Lapisan luar sel-sel baru mengalami pembelahan berkali-kali untuk membentuk jaringan korteks sehingga terjadi proses penyembuhan luka dan regenerasi. Terdapat perbedaan pada sistem kultur sel dan kultur jaringan makroalga. Pada sistem kultur sel, massa sel pada umumnya berupa filamen-filamen dan multiseluler, sedangkan pada sistem kultur jaringan, jaringan talus terdiri atas jaringan-jaringan tunas dan filamen-filamen berserabut yang biasanya berasal dari bagian medular (Kumar et al., 2004; Muraoka et al., 1998; Rorrer \& Cheney, 2004). Pada kultur jaringan rumput laut, regenerasi terjadi melalui dua proses yakni melalui pembentukan kalus (embriogenesis) atau pembentukan tunas secara langsung (organogenesis). Peran media sangat memengaruhi model pembentukan tunas, pada media padat biasanya tunas terbentuk melalui proses embriogenesis, sedangkan pada media cair eksplan cenderung langsung membentuk tunas (Kumar et al., 2007; Kumar et al., 2004).

\section{Aklimatisasi di Tambak}

Nilai bobot mutlak tertinggi diperoleh pada perlakuan C ( $30 \mathrm{~g} / \mathrm{hapa})$ dengan nilai sebesar $630,00 \mathrm{~g}$; kemudian perlakuan B ( $20 \mathrm{~g} / \mathrm{hapa})$
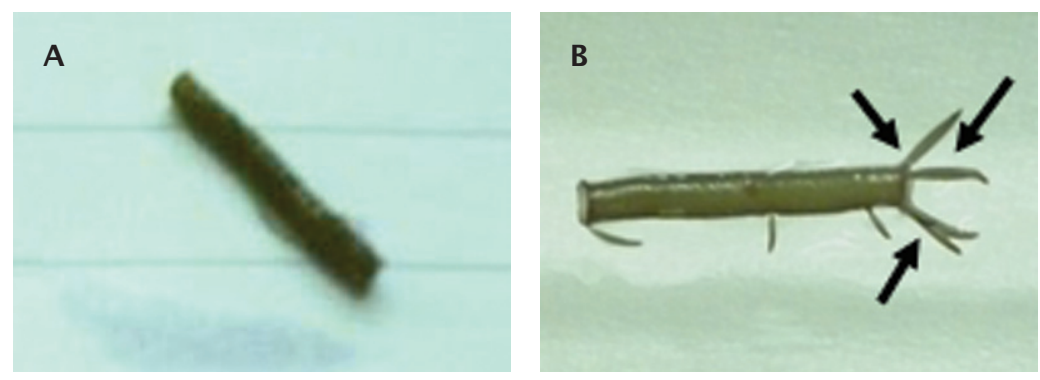

Gambar 4. Kondisi eksplan pada awal kultur (A); tunas terbentuk pada bagian sayatan eksplan (tanda panah) setelah delapan minggu masa kultur (B)

Figure 4. Explant of Gracilaria sp. at the beginning of culture time (A); the shoots was formed on cut surface (arrows) after eight weeks of culture time (B) 
sebesar 396,67 g; dan nilai terendah terdapat pada perlakuan A ( $10 \mathrm{~g} /$ hapa) dengan nilai sebesar 365,00 g. Hasil analisis ragam (ANOVA) menunjukkan bahwa bobot eksplan yang berbeda memberikan pengaruh yang nyata $(P<0,05)$ terhadap bobot mutlak bibit rumput laut Gracilaria sp. Pada Gambar 5 terlihat bahwa semakin lama waktu pemeliharaan, bobot eksplan semakin meningkat. Hal ini memperlihatkan bahwa semakin lama waktu aklimatisasi, eksplan semakin mampu beradaptasi dengan lingkungan perairan sehingga kondisi eksplan semakin stabil dan dapat tumbuh dan berkembang dengan baik, selain daripada itu, kondisi tambak juga mendukung untuk pertumbuhan rumput laut.

Pertumbuhan rumput laut dipengaruhi oleh faktor eksternal dan faktor internal. Faktor internal yang berpengaruh terhadap pertumbuhan rumput laut antara lain bagian talus dan umur, sedangkan faktor eksternal yang berpengaruh antara lain keadaan lingkungan fisik dan kimiawi perairan. Pada penelitian ini, perbedaan bobot mutlak yang terjadi disebabkan oleh perbedaan bobot awal yang berbeda. Faktor kedalaman hapa juga harus diperhatikan dalam kegiatan aklimatisasi agar bibit rumput laut mendapat paparan cahaya matahari yang cukup sehingga dapat tumbuh dengan baik, karena rumput laut yang dipelihara mendekati permukaan air memiliki pertumbuhan yang lebih baik (Ren et al., 1984; Kim \& Humm, 1965).

Laju pertumbuhan bobot harian pada perlakuan A sebesar 7,58\%/hari; perlakuan B sebesar $6,14 \% /$ hari; dan perlakuan $C$ sebesar 5,01\%/hari (Gambar 6). Hasil analisis ragam (ANOVA) memperlihatkan bahwa perbedaan kepadatan hingga $30 \mathrm{~g} /$ hapa tidak memberikan pengaruh yang signifikan terhadap LPH bobot rumput laut $(P>0,05)$. Hal yang sama juga terjadi pada laju pertumbuhan panjang harian di mana pada penelitian ini diperoleh hasil perlakuan A sebesar 2,91\%/hari; perlakuan B sebesar 2,64\%/hari; dan perlakuan $C$ sebesar 2,37\%/hari (Gambar 7). Hasil analisis ragam (ANOVA) juga tidak memperlihatkan pengaruh yang signifikan terhadap LPH panjang $(P>0,05)$.

Kedua hasil tersebut memperlihatkan bahwa pada kegiatan aklimatisasi, kepadatan 10 $\mathrm{g} /$ hapa hingga $30 \mathrm{~g} /$ hapa masih dapat ditolerir untuk pertumbuhan bibit, di mana bibit rumput laut masih dapat tumbuh dan berkembang dengan baik pada kepadatan tersebut. Kepadatan merupakan hal yang perlu diperhatikan karena terdapat korelasi antara kepadatan organisme dan kompetisi dalam hal pemanfaatan nutrien perairan, kompetisi tersebut dapat mengakibatkan terhambatnya pertumbuhan bahkan kadang-kadang dapat mengakibatkan kematian organisme (Guanzon \& Castro, 1992).

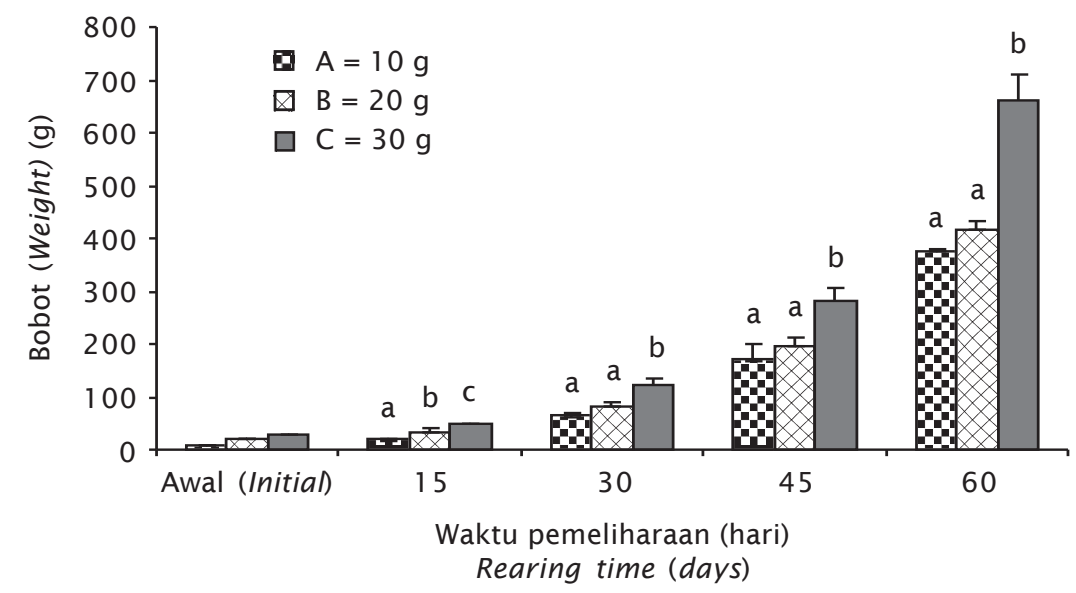

Keterangan (Note):

Nilai yang diikuti huruf yang sama setelah nilai rata-rata menunjukkan berbeda tidak nyata $(P>0,05)$ pada uji LSD (Values with the same superscripts after means value are not significantly different $(P>0.05)$ in LSD test)

Gambar 5. Bobot eksplan rumput laut Gracilaria sp. setiap 15 hari

Figure 5. Weight of Gracilaria sp. explants every 15 days 


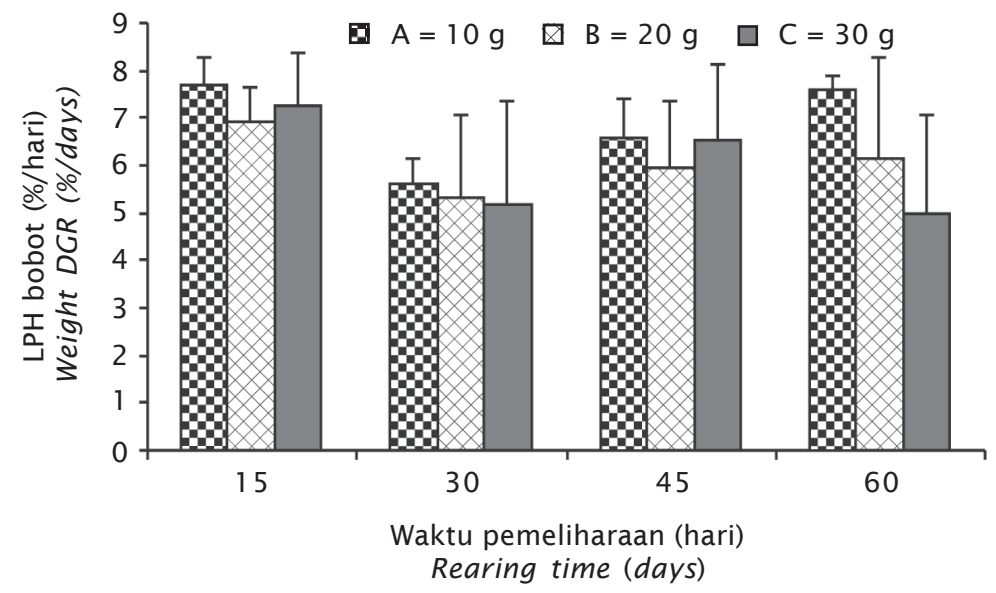

Gambar 6. Laju pertumbuhan bobot bibit rumput laut Gracilaria sp. hasil kultur jaringan

Figure 6. Daily growth rate weight of tissue culture seaweed seed Gracilaria sp.

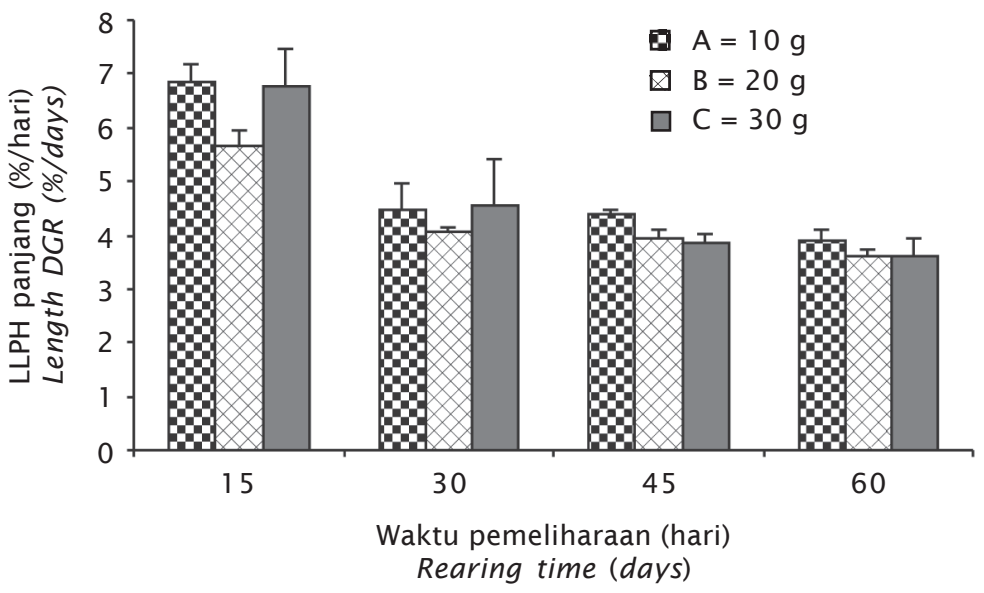

Gambar 7. Laju pertumbuhan panjang bibit rumput laut Gracilaria sp. hasil kultur jaringan

Figure 7. Daily growth rate length of tissue culture seaweed seed Gracilaria sp.

Referensi mengenai laju pertumbuhan eksplan rumput laut Gracilaria sp. hasil kultur jaringan masih sangat terbatas, namun untuk spesies lain telah dilaporkan oleh Hernandez et al. (2007) yang menjelaskan bahwa eksplan rumput laut Gigartina skottsbergii hasil propagasi in vitro dapat tumbuh pada saat dipindahkan ke lapangan dengan laju pertumbuhan yang sama dengan pemeliharaan di laboratorium, yakni sebesar 0,5\%/hari. Menurut Kim et al. (2005), laju pertumbuhan panjang relatif rumput laut $G$. chorda pada kultur vegetatif dari fragmen talus tunggal berada pada kisaran 1,6\%-6,7\%.

Perkembangan bibit pada aklimatisasi dan pembesaran di tambak setiap minggu disajikan pada Gambar 8.

Pada umur satu minggu, eksplan rumput laut memiliki tunas yang lebih panjang dibandingkan pada awal aklimatisasi (Gambar $8 \mathrm{~A}$ dan 8B). Bibit rumput laut Gracilaria sp. hasil 

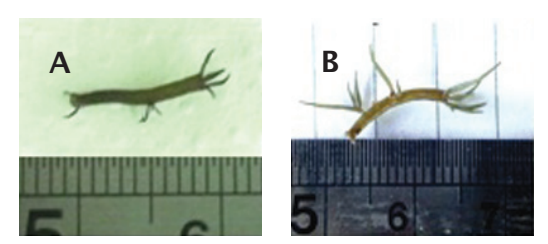
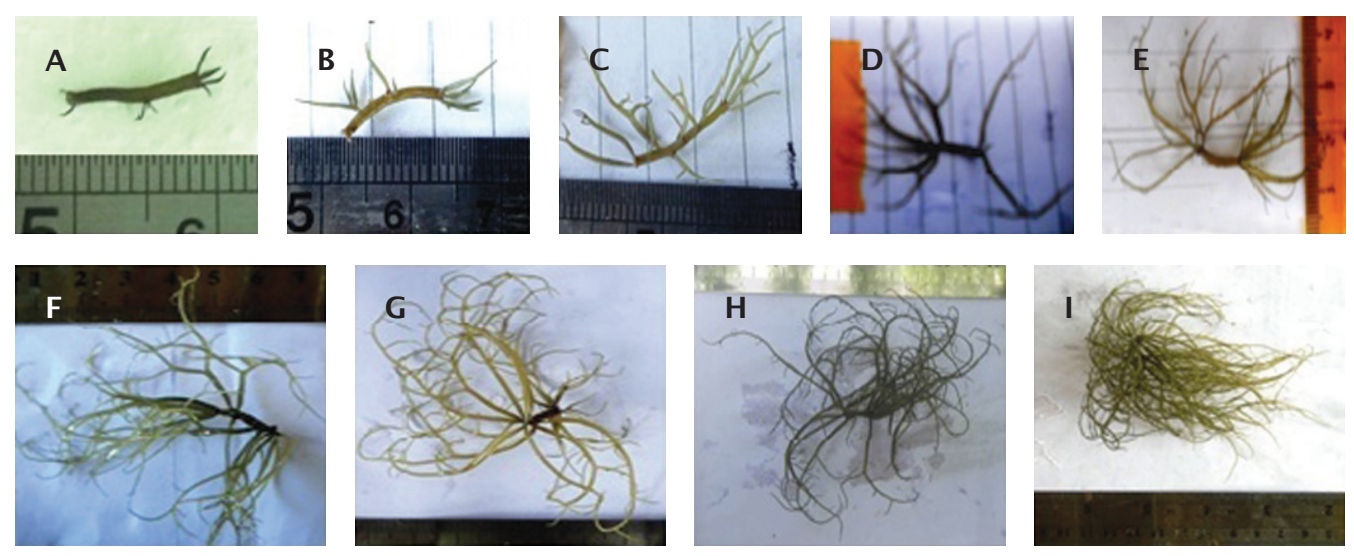

Gambar 8. Perkembangan bibit Gracilaria sp. selama 60 hari pemeliharaan. $A=A w a l ; B=$ Minggu ke- $1 ; C=$ Minggu ke-2; $D=$ Minggu ke-3; $E=$ Minggu ke-4; $F=$ Minggu ke-5; $G=$ Minggu ke-6; $\mathrm{H}=$ Minggu ke-7; I = Minggu ke-8

Figure 8. Development of Gracilaria sp. seed in 60 days acclimation. $A=$ In the beginning of acclimation; $B=$ First week; $C=$ Second week; $D=$ Third week; $E=$ Fourth week; $F=$ Fifth week; $G$ = Sixth week; $H$ = Seventh week; I = Eighth week

kultur jaringan mengalami regenerasi dengan cepat pada umur pemeliharaan dua minggu (Gambar 8C), diduga pada umur pemeliharaan tersebut eksplan sudah mampu beradaptasi dengan lingkungan budidaya sehingga dapat berkembang dengan baik. Pada umur pemeliharaan 3-7 minggu talus semakin bertambah panjang dan percabangan semakin banyak (Gambar 8D-8H). Setelah aklimatisasi selama delapan minggu, eksplan berkembang menjadi bibit rumput laut dewasa yang memiliki talus kuat dan percabangan yang banyak dan panjang sehingga bibit siap untuk diperbanyak di tambak (Gambar 8I).

Rorrer \& Cheney (2004) menjelaskan bahwa secara umum perkembangan bioproses alga laut terdiri atas proses bioteknologi dan akuakultur. Proses bioteknologi merupakan proses seluler-molekuler yang dilakukan di laboratorium untuk menghasilkan eksplan, sedangkan proses aklimatisasi eksplan di tambak merupakan rangkaian dari proses bioteknologi yang merupakan proses akuakultur.

\section{Propagasi di Tambak}

Propagasi di tambak dilakukan selama buIan Juni-Oktober 2013. Laju pertumbuhan harian selama perbanyakan berada pada kisaran 2,33\%-4,31\% (Gambar 9). LPH tertinggi diperoleh pada bulan Agustus (4,31\%) dan terendah pada bulan Oktober (2,33\%). Rata-rata LPH per bulan sebesar 3,57\%/hari; nilai ini lebih rendah dari nilai rata-rata LPH Gracilaria bailinai yang diperoleh Hurtado-Ponce et al. (1997) yakni sebesar 4,5\%/hari. Penurunan LPH terjadi pada bulan Juli, kemudian meningkat dan puncaknya terjadi pada bulan Agustus, setelah itu, terjadi penurunan hingga bulan Oktober.

Kondisi musim selama propagasi di tambak sangat memengaruhi performa pertumbuhan bibit rumput laut. Bulan Juni hingga bulan Juli merupakan masa peralihan musim hujan ke musim kemarau, di mana salinitas berada pada kisaran 23-24 g/L dan suhu perairan pada kisaran $28^{\circ} \mathrm{C}-29^{\circ} \mathrm{C}$, sedangkan pada bulan Agustus hingga Oktober merupakan musim kemarau dengan salinitas berkisar pada 24$38 \mathrm{~g} / \mathrm{L}$ dan suhu pada kisaran $29^{\circ} \mathrm{C}-35^{\circ} \mathrm{C}$. Suhu perairan pada bulan Agustus-Oktober tergolong tinggi, hal ini menyebabkan terjadinya penurunan pertumbuhan rumput laut pada bulan tersebut. Suhu memiliki korelasi yang signifikan dengan pertumbuhan rumput laut Gracilaria sp., suhu terbaik untuk pertumbuhan spesies Gracilaria sp. pada kisaran $20^{\circ} \mathrm{C}$ $28^{\circ} \mathrm{C}$ (Orduña-Rojas \& Robledo, 2002; Raikar et al. 2001). Salinitas optimum untuk pertumbuhan Gracilaria sp. adalah $25 \mathrm{~g} / \mathrm{L}$, namun Gracilaria sp. diketahui mampu tumbuh dengan baik pada kisaran salinitas yang lebar, yakni 13-40 g/L (Jansi \& Ramadhas, 2009). Peubah kualitas air yang lain selama propagasi di tambak cukup bervariasi, yakni: nitrat $(0,066$ 0,420 mg/L); nitrit (0,0003-0,021 mg/L); dan 


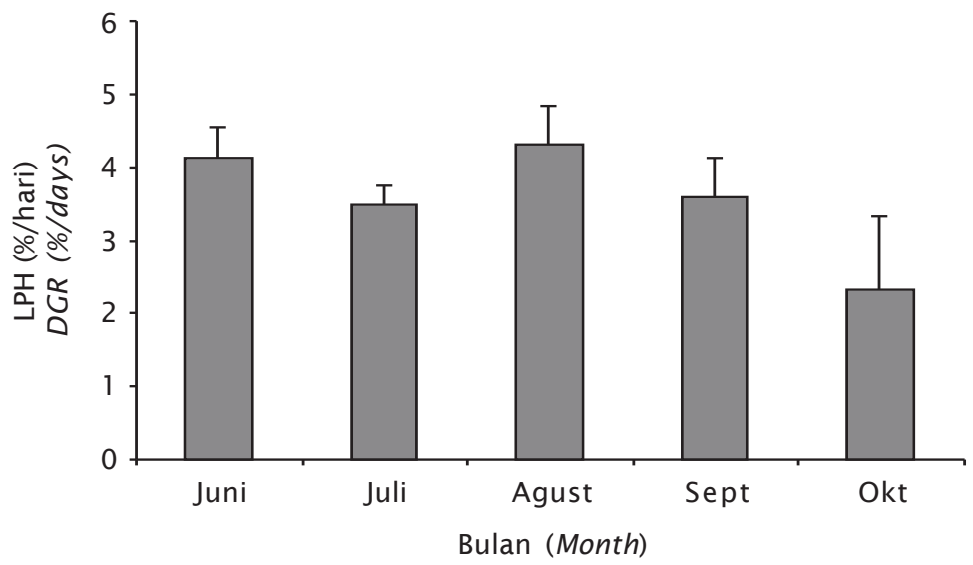

Gambar 9. Laju pertumbuhan harian bibit rumput laut Gracilaria sp. hasil kultur jaringan selama perbanyakan di tambak

Figure 9. Daily growth rate of Gracilaria sp. tissue culture during propagation in pond

fosfat $(0,049-0,230 \mathrm{mg} / \mathrm{L})$. Peubah kualitas air tersebut masih berada pada kisaran yang baik untuk kegiatan budidaya. Batas toleransi nitrat terendah untuk pertumbuhan alga adalah 0,1 $\mathrm{mg} / \mathrm{L}$; sedangkan batas tertingginya adalah 3 $\mathrm{mg} / \mathrm{L}$, kandungan fosfat dalam perairan digolongkan dalam tiga kategori, yakni perairan dengan tingkat kesuburan rendah memiliki kandungan fosfat pada kisaran 0-0,02 mg/L; tingkat kesuburan sedang pada kisaran 0,021$0,05 \mathrm{mg} / \mathrm{L}$; dan kesuburan tinggi pada kisaran 0,051-0,2 mg/L; kadar nitrit di perairan secara alami berada pada kisaran $0,001 \mathrm{mg} / \mathrm{L}$ dan sebaiknya tidak melebihi $0,05 \mathrm{mg} / \mathrm{L}$ karena dapat bersifat toksik bagi organisme perairan (Moore, 1991; Effendi, 2003). Alga memerlukan ketersediaan unsur hara seperti nitrogen dan fosfat dalam perairan untuk tumbuh. Masuknya unsur hara ke dalam jaringan tubuh rumput laut melalui proses difusi yang terjadi pada seluruh bagian permukaan tubuh rumput laut. Bila proses difusi semakin sering terjadi, akan mempercepat proses metabolisme sehingga akan meningkatkan laju pertumbuhan (Doty, 1971).

Perkembangan bibit rumput laut Gracilaria sp. pada setiap tahapan dan alokasi waktu yang diperlukan pada propagasi vegetatif dengan teknik kultur jaringan disajikan pada Gambar 10. Upaya untuk mendapatkan bibit rumput laut yang siap digunakan dalam kegiatan budidaya diperlukan waktu hingga enam bulan, selanjutnya adalah kegiatan perbanyakan bibit.
Penelitian ini dapat membuktikan bahwa produksi massal bibit rumput laut Gracilaria sp. untuk mendukung kegiatan budidaya memungkinkan dilakukan melalui kultur jaringan. Hal yang sama juga telah dilakukan pada penelitian-penelitian sebelumnya pada berbagai jenis rumput laut di antaranya: Kappaphycus alvarezii (Paula et al., 2001; Reddy et al., 2003; Muñoz et al., 2006); Eucheuma denticulatum (Hurtado \& Cheney, 2003); Heterosiphonia japonica (Husa \& Sjøtun, 2006); dan Gelidiella acerosa (Kumar et al., 2004).

Menurut Reddy et al. (2008), perkembangan teknologi kultur in vitro merupakan hal yang penting pada bioteknologi rumput laut dan memiliki peranan sentral pada industri global rumput laut di masa mendatang. Propagasi vegetatif rumput laut Gracilaria sp. melalui kultur jaringan merupakan upaya untuk memenuhi kebutuhan bibit rumput laut secara kontinu. Evaluasi terhadap pertumbuhan dan perkembangan eksplan pada kultur in vitro hingga propagasi di lapangan memudahkan untuk memprediksi waktu yang diperlukan untuk menyediakan bibit, serta memudahkan dalam penelusuran umur bibit yang akan digunakan pada kegiatan budidaya. Hal tersebut merupakan informasi penting karena berkaitan dengan ketersediaan dan kualitas bibit rumput laut yang akan digunakan dalam kegiatan budidaya untuk menunjang peningkatan produksi rumput laut secara global. 


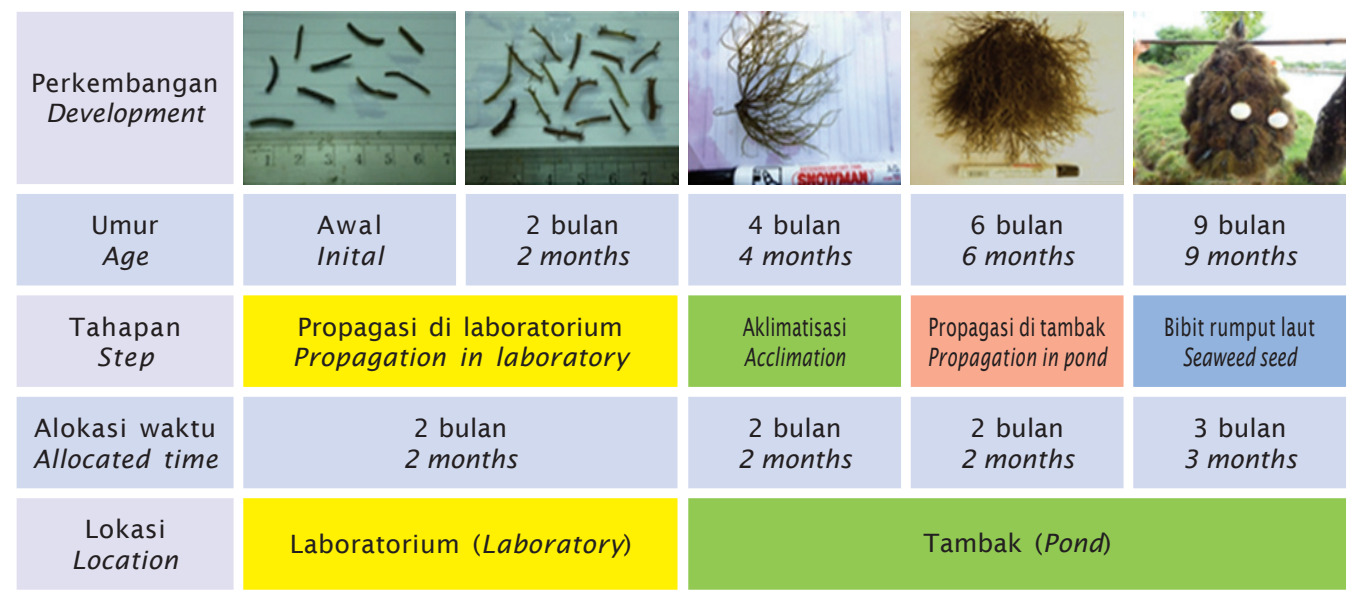

Gambar 10. Perkembangan bibit Gracilaria sp. pada setiap tahapan dan alokasi waktu yang diperlukan pada propagasi vegetatif melalui kultur jaringan

Figure 10. Development of Gracilaria sp. seed in every step and allocated time of vegetative propagation by tissue culture

\section{KESIMPULAN}

Pada propagasi di laboratorium, sintasan tertinggi sebesar $45,38 \%$ diperoleh pada kepadatan 1.500 eksplan/kontainer, tunas mulai tumbuh setelah delapan minggu masa kultur. Kepadatan eksplan $30 \mathrm{~g} / \mathrm{hapa}$ memiliki $\mathrm{LPH}$ yang sama dengan kepadatan $10 \mathrm{~g} / \mathrm{hapa}$ dan $20 \mathrm{~g} /$ hapa sehingga disarankan pada kegiatan aklimatisasi menggunakan kepada$\tan 30 \mathrm{~g} /$ hapa. Laju pertumbuhan bibit rumput laut Gracilaria sp. hasil kultur jaringan pada propagasi di tambak berada pada kisa$\operatorname{ran} 2,33 \%-4,31 \%$.

\section{UCAPAN TERIMA KASIH}

Terima kasih disampaikan kepada Edy Irawan dan segenap teknisi laboratorium kultur jaringan yang telah membantu dalam kegiatan penelitian. Penelitian ini dibiayai oleh dana DIPA APBN Tahun Anggaran 2013.

\section{DAFTAR ACUAN}

Bixler, H.J. \& Porse, H. 2011 . A decade of change in the seaweed hydrocolloids industry. $J$. Appl. Phycol., 23: 321-335.

Cecere, E., Petrocelli, A., \& Verlaque, M. 2011. Vegetative reproduction by multicellular propagules in Rhodophyta: an overview. Marine Ecology, 32: 41 9-437.

Dawes, C.J., Kovach, C., \& Friedlander, M. 1993. Exposure of Gracilaria to various envi- ronmental conditions II. The effect on fatty acid composition. Bot. Mar., 36: 289-296.

Doty, M.S. 1971. Measurement of water movement in references to benthic algae growth. Bot. Mar., 14: 32-35.

Effendi, H. 2003. Telaah kualitas air: bagi pengelolaan sumber daya dan lingkungan perairan. Kanisius. Yogyakarta, $257 \mathrm{hlm}$.

FAO. 2012. The state of world fisheries and aquaculture 2012. Rome, 209 pp.

George, E.F. \& Sherrington, P.D. 1984. Plant propagation by tissue culture. Handbook and Directory of Commercial Laboratories. Reading, UK. Eastern Press, 709 pp.

Guanzon, N.G. \& Castro, T.R. 1992. The effects of different stocking densities and some abiotic factors on cage culture of $\mathrm{Gra}$ cilaria sp. (Rhodophyta, Gigartinales). Bot. Mar., 35: 239-243.

Hernández-González, M.C., Buschmann, A.H. Cifuentes, M., Correa, J.A., \& Westermeier, R. 2007. Vegetative propagation of the carrageenophytic red alga Setchell et Gardner: Indoor and field experiments. Aquaculture, 262: 120-128.

Huang, W. \& Fujita, Y. 1997. Callus induction and thallus regeneration of the red alga Meristotheca papulosa (Rhodophyta, Gigartinales). Bot. Mar., 40: 55-61.

Huang, Y., Maliakal, S., Cheney, D.P., \& Rorrer, G.L. 1998. Comparison of development and photosynthetic growth for filament 
clump and regenerated microplantlet culture of Agardhiella subulata (Rhodophyta, Gigartinales). J. Phycol., 34: 893-901.

Hurtado-Ponce, A.Q., Agbayani, R.F., \& SamonteTan, G.P.B. 1997. Growth rate, yield and economics of Gracilariopsis bailinae (Gracilariales, Rhodophyta) using fixed bottom long line method. The Philippine Journal of Science, 126(3): 251-260.

Hurtado-Ponce, A.Q. \& Cheney, D.P. 2003. Propagule production of Eucheuma denticulatum (Burman) Collins et Harvey by tissue culture. Bot. Mar., 46: 338-341.

Husa, V. \& Sjøtun, K. 2006. Vegetative reproduction in "Heterosiphonia japonica" (Dasyaceae, Ceramiales, Rhodophyta), an introduced redalga on European coasts. Bot. Mar., 49: 191-199.

Jansi, M. \& Ramadhas, V. 2009. Effect of salinity and dissolved nutrients on the occurrence of some seaweeds in Manakkudy estuary. Indian Journal of Marine Sciences, 38(4): 470-473.

Kim, C.S. \& Humm, H.J. 1965. The red alga, Gracilaria foliifera with special reference to the cell wall polysaccharides. Bull. Mar. Sci., 15: 1,036-1,050.

Kim, J.H., Lee, S.D., Choil, S.J., Chung, I.K., \& Shin, J.A. 2005. Cultivation of Gracilaria chorda (Gracilariales, Rhodophyta) by Vegetative Regeneration. Algae, 20(2): 141-150.

Kumar, G.R., Reddy, C.R.K., Ganesan, M., Thiruppathi, S., Dipakkore, S., Eswaran, K., Rao, P.V.S., \& Jha, B. 2004. Tissue culture and regeneration of thallus from callus of Gelidiella acerosa (Gelidiales, Rhodophyta). Phycologia, 43(5): 596-602.

Kumar, G.R., Reddy, C.R.K., \&Jha, B. 2007. Callus induction and thallus regeneration from callus ofphycocolloid yielding seaweeds from the Indian coast. J. Appl. Phycol., 19: 15-25.

Luhan, M.R.J. \& Sollesta, H. 2010 . Growing the reproductive cells (carpospores) of the seaweed, Kappaphycus striatum, in the laboratory until outplanting in the field and maturation to tetrasporophyte. J. Appl. Phycol., 22: 579-585.

Moore, J.W. 1991. Inorganic contaminants of surface water research and monitoring priorities. Springer-Verlag. New York, 334 pp.

Muñoz, J., Cahue-Lõpez, A.C., Patiño, R., \& Robledo, D. 2006. Use of plant growth regulators in micropropagation of Kappaphycus alvarezii (Doty) in airlift bioreactors. J. Appl.
Phycol., 18: 209-218.

Muraoka, D., Yamamoto, H., Yasuiu, H., \& Terada, R. 1998. Formation of wound tissue of Gracilaria chorda Holmes (Gracilariaceae) in culture. Hokkaido Universty. Bull. Fac. Fish., 49(1): 31-39.

Orduña-Rojas, J. \& Robledo, D. 2002. Studies on the tropical agarophyte Gracilaria cornea J. Agardh (Rhodophyta, Gracilariales) from Yucatán, México II. Biomass Assessment and Reproductive Phenology. Bot. Mar., 45: 459-464.

Paula, E.J., Erbert, C., \& Pereira, R.T.L. 2001. Growth rate of the carrageenophyte Kappaphycus alvarezii (Rhodophyta, Gigartinales) in vitro. Phycological Research, 49: 155-161.

Polne-Fuller, M. \& Gibor, A. 1984. Developmental studies in Porphyra. I. Blade differentiation in Porphyra perforata as expressed by morphology, enzymatic digestion and protoplast regeneration. J. Phycol., 20: 609616.

Pong_Masak, P.R., Parenrengi, A., Tjaronge, M., \& Rusman. 2011 . Protokol seleksi varietas bibit unggul rumput laut. Balai Penelitian dan Pengembangan Budidaya Air Payau, Maros. Pusat Penelitian dan Pengembangan Perikanan Budidaya. Kementerian Kelautan dan Perikanan. $27 \mathrm{hlm}$.

Provasoli, L. 1968. Media and prospects for the cultivation of marine algae. In Watanabe, A. \& Hattori, A. (Eds.), Cultures and collections of algae. Proceedings of the U.S.Japan Conference. Japanese Society of Plant Physiology, Hakone, p. 63-75.

Raikar, S.V., lima, M., \& Fujita, Y. 2001. Effect of temperature, salinity and light intensity on the growth of Gracilaria spp. (Gracilariales, Rhodophyta) from Japan, Malaysia and India. Indian Journal of Marine Sciences, (30): 98-104.

Reddy, C.R.K., Kumar, G.R., Siddhanta, A.K., \& Tewari, A. 2003. In vitro somatic embryogenesis and regeneration of somatic embryos from pigmented callus of Кappaphycus alvarezii (Doty) Doty (Rhodophyta, Gigarti-nales). J. Phycol., 39: 610-616.

Reddy, C.R.K., Jha, B., Fujita, Y., \& Ohno, M. 2008. Seaweed micropropagation techniques and their potentials: an overview. J. Appl. Phycol., 20: 609-617.

Ren, G.Z., Wang, J.C., \& Chen, M.Q. 1984. Cultivation of Gracilaria by means of low rafts. Hydrobiologia, 116/1 17: 72-76. 
Rorrer, G.L. \& Cheney, D.P. 2004. Bioprocess engineering of cell and tissue cultures for marine seaweeds. Aquaculture Engineering, 32: 11-41.

Simpson, F.J., Shacklock, P.F., Robson, D., \& Neish, A.C. 1979. Factors affecting cultivation of Chondrus crispus (Florideophyceae). Proceedings of the $9^{\text {th }}$ International Seaweed Symposium, p. 509-523.

Skurzynski, P. \& Bocia, K. 2011. Vegetative propagation of Chara rudis (Characeae, Chlorophyta). Phycologia, 50(2): 194-201.

Tseng, C.K. 2004. The past, present and future of phycology in China. Hydrobiologia, 512: 11-20.

Yokoya, N.S., Kakita, H., Obika, H., \& Kitamura, T. 1999. Effect of environmental factors and plant growth regulators on growth of the red alga Gracilaria vermiculophylla from Shikoku Island, Japan. Hydrobiologia, 398/399: 339-347.
Yokoya, N.S. \& Valentin, Y.Y. 2011 . Micro-propagation as a tool for sustainable utilization and conservation of populations of Rhodophyta. Brazilian Journal of Pharmacognosy, 21 (2): 334-339.

Yokoya, N.S., Plastino, E.M., \& Artel, R. 2003. Physiologicalresponses and pigment characterization of two colour strains of the carrageenophyte Hypnea musciformis (Rhodophyta). Proceedings of the $17^{\text {th }}$ International Seaweed Symposium, p. 425434.

Yong, W.T.L., Ting, S.H., Yong, Y.S., Thien, V.Y., Wong, S.H., Chin, W.L., Rodrigues, K.F., \& Anton, A. 2014. Optimization of culture conditions for the direct regeneration of Kappaphycus alvarezii (Rhodophyta, Solieriaceae). J. Appl. Phycol., 26: 1,5971,606 . 